wiedzi na tym samym poziomie dyskursu. Zagęszczenie wypowiedzi o estetycznych i polityczno-kulturalnych uwarunkowaniach w dwóch niegdyś komunistycznych krajach, które na bardzo różne sposoby przeżyły kulturowe przełomy, pozwala na zaskakujące, intensywne wejrzenia w artystyczne scenerie obu krajów, dzięki którym ich najbardziej kreatywne postaci ukazują publiczności swoje (nie)oblicze. Przekaz ten wzmacnia zdjęcie na okładce tomu: Artjom Loskutow jako rosyjski Spiderman i Paweł Althamer (Polska), ukryty za maską okularów spawalniczych.

(Wolfgang Schlott, przeł. Emilia Kledzik) ale wniósł do nich ogromny twórczy wkład. Pełniąc funkcję Junior Fellow w Harvard Society of Fellows udał się ponownie na Bałkany już w roku 1937. Do Jugosławii powracał wielokrotnie, najbardziej znacząca była podróż w latach 1950-1951, podczas której Lord zdołał w spektakularny sposób zrealizować zamysły badawcze Parry'ego. Efektem jego prac jest książka Singer of Tales (1960, Pieśniarz i jego opowieść), której przekład ukazał się w roku 2010 nakładem Wydawnictw Uniwersytetu Warszawskiego w serii „Communicare". Niniejszy przekład oparty jest na drugim, niezmienionym wydaniu Pieśniarza z roku 2000; uzupełniono je jedynie o materiały audiowizualne: fragmenty nagrań, fotografie oraz faksymile zapisów nutowych pieśni.

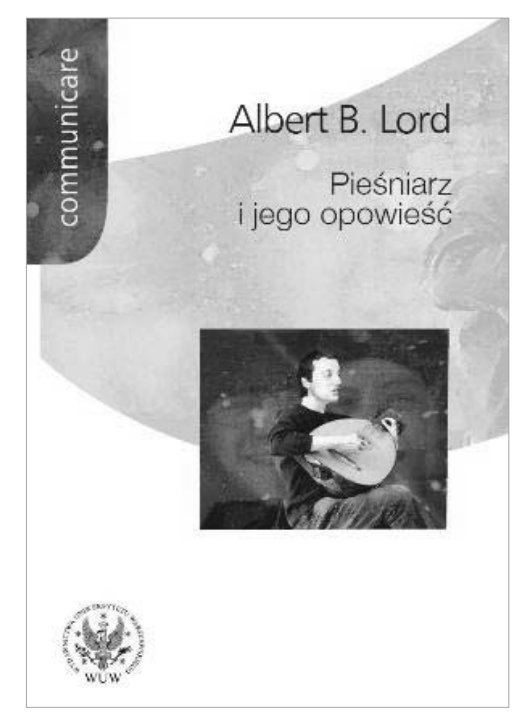

Pieśniarz i jego opowieść składa się z dwóch części. Pierwsza część poświęcona jest zagadnieniom teoretycznym dotyczącym techniki kompozycji, struktury pieśni oraz funkcjonowaniu tradycji ustnej. Lord 
omawia między innymi kwestie formuły będącej podstawą kompozycji ustnej, procesu wykonania i nauki pieśni, struktury pieśni, wariantywności wykonań, wreszcie samej tradycji ustnej i tradycji piśmiennej oraz zagadnienia procesu przechodzenia z jednej do drugiej. Część druga stanowi przykład zastosowania owej teorii $\mathrm{w}$ praktyce, tj. „zbadania form niektórych wielkich poematów epickich" (eposów homerowych oraz epiki średniowiecznej, m.in. staroangielskiej i starofrancuskiej). Do książki dołączony jest obszerny aneks zawierający przykłady pieśni południowosłowiańskich z archiwum Parry'ego, obecnie przechowywanego jako Milman Parry Collection w Wiedener Library (sala C) na Uniwersytecie Harvarda. Fragmenty pieśni bohaterskich i rozmów (wywiadów sterowanych) z pieśniarzami, cytowanych przez Alberta Lorda obszernie $\mathrm{w} X$ rozdziale książki, znajdziemy na dołączonej do książki płycie $\mathrm{z}$ archiwalnymi nagraniami. $\mathrm{Na}$ płycie znajdują się również archiwalne fotografie opisane przez Lorda oraz faksymile rękopisów Beli Bartòka z transkrypcjami niektórych pieśni cytowanych przez Lorda w swojej książce.

Pieśniarz jest książką komparatystyczną, co podkreśla autor w pierwszych słowach "Przedmowy": "Jest to książka o Homerze. On jest naszym pieśniarzem śpiewającym opowieści. Zarazem jednak, w szerszym sensie reprezentuje wszystkich pieśniarzy śpiewających opowieści od niepamiętnych czasów zamierzchłej przeszłości aż po dzień dzisiejszy. Nasza książka dotyczy ich w stopniu nie mniejszym niż jego. Każdy z nich, nawet najskromniejszy, należy do tradycji oralnej pieśni epickiej dokładnie tak samo, jak należy do niej Homer - jej najbardziej utalentowany przedstawiciel. Wśród pieśniarzy żyjących w naszych czasach nikt mu nie dorównuje, ale tym, który, przynajmniej według naszego doświadczenia, zbliża się do Mistrza najbardziej, jest Avdo Međedović z miejscowości Bijelo Polje w Jugosławii. On jest naszym dzisiejszym bałkańskim Pieśniarzem śpiewającym opowieści." Jest to zabieg celowy i w pełni świadomy: zestawienie epiki greckiej z żywą tradycją południowosłowiańską pozwoliło autorowi na wyjaśnienie zasad funkcjonowania tradycji ustnej i analize procesu komponowania oraz wykonywania pieśni. Lord starał się udzielić odpowiedzi na niezwykle frapujące $\mathrm{w}$ tamtym czasie pytanie o metody, jakimi posługiwali się twórcy eposów ustnych, w tym Homer, w układaniu nowych pieśni. Dzięki analizie procesu twórczego pieśniarzy południowosłowiańskich Lord dokonał swoistej rekonstrukcji techniki poesis Homera. Było to możliwe właśnie dzięki materiałowi zgromadzonemu przez Parry'ego i Lorda.

Książka Lorda jest książką prekursorską, twórczość ustna ujęta jest w kategoriach holistycznych, proces twórczy analizowany jest jako szereg dynamicznych powiązań i zależności, w których istotną rolę odgrywa nie tylko wykonawca, ale również słuchacze. Ważny jest kontekst, a nawet geografia, ponieważ Lord dowodzi, że formuły mają charakter geograficzny, a miejsce zamieszkania pieśniarza w znacznym stopniu wpływa na tkankę językową pieśni. Podkreśla zakorzenienie opowieści w lokalnej kulturze i historii oraz nierozerwalność pieśni z procesem jej wykonania. W sposób nowatorski łączy podejście krytycznoliterackie $\mathrm{z}$ analizą psychodynamiki opowieści, pokazuje, w jaki sposób performance wpływa na twórczość ustną i sposób kompozycji ustnej.

Książka jest również cennym podręcznikiem folklorystyki, z powodzeniem może służyć jako drogowskaz w badaniach tere- 
nowych. Obaj, Parry i Lord byli znakomitymi badaczami terenowymi, co niewątpliwie wpłynęło na sukces ich badań. Lord dokładnie opisuje proces przygotowań do badań terenowych, ich przebieg oraz wyniki. Nie pomija technicznych szczegółów towarzyszącym nagraniom, relacjonuje również treść rozmów z pieśniarzami. Lord wyznaczył nowy kierunek w badaniach nad folklorem.

Pieśniarz i jego opowieść obrazuje również zmiany, jakie towarzyszą procesowi przejścia z kultury oralnej do piśmiennej, przedstawia ginący świat pieśniarzy i ich opowieści; mówi o zmianach, jakie zaszły i wciąż zachodzą w tradycyjnych kulturach i społecznościach, akcentuje również zjawisko wtórnej oralności.

Wpływ dziedzictwa Parry'ego-Lorda wykracza daleko poza literaturoznawstwo klasyczne, południowosłowiańskie, a nawet komparatystykę, obejmując studia nad wieloma literaturami oralnymi i piśmiennymi. Jak słusznie zauważają we wstępie do nowego wydania Stephen Mitchell and Gregory Nagy: „Lord i Parry antycypowali w swoich pracach nie tylko metody badania tradycji i gatunków folkloru, ale co najmniej dwa wpływowe podejścia teoretyczne stosowane dziś do badania folkloru - etnopoetykę $\mathrm{z}$ jej głębokim zaangażowaniem w kwestię kulturowych matryc artystycznego performance oraz performatykę $\mathrm{z}$ jej holistycznym ujęciem dynamicznego procesu twórczego i jego relacji zarówno wobec wykonawcy, jak i wobec publiczności ${ }^{1}$."

\section{(Agnieszka Matkowska)}

${ }^{1}$ S. Mitchell, G. Nagy, Wprowadzenie do nowego wydania w: A. B. Lord, Pieśniarz i jego opowieść. Przekład P. Majewski. Warszawa 2010, s. 26-27.
Csaba G. Kiss, Lekcja Europy Środkowej. Eseje i szkice. Kraków 2009, ss. 318.

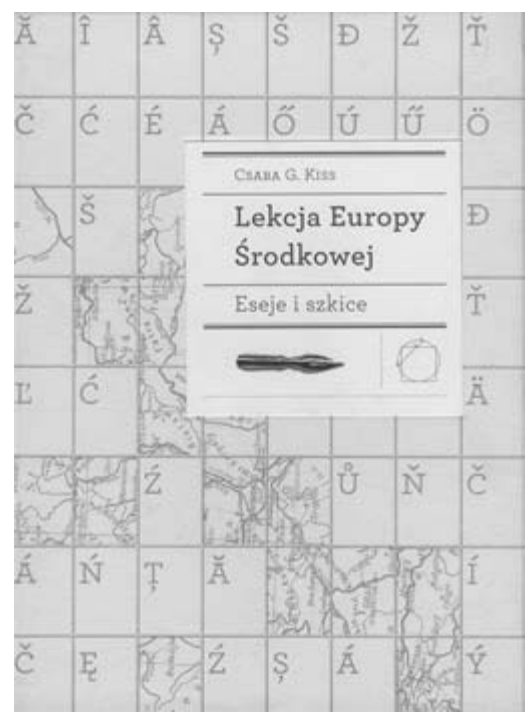

Wydany nakładem krakowskiego Międzynarodowego Centrum Kultury tom esejów Csaby G. Kissa obejmuje teksty publikowane wcześniej w latach 1986-2006 w czasopismach literackich (m. in.: "Tygodniku Powszechnym”, ,Akcencie”, ,Literaturze na Świecie”, „Krasnogrudzie”, paryskiej "Kulturze”) i tomach zbiorowych. Prace węgierskiego znawcy kultury, historii i literatury Europy Środkowej i Wschodniej zostały podzielone na cztery części, w każdej z nich znalazły się szkice poświęcone zarówno problemom tożsamości narodowej, dziedzictwa kulturowego, zawiłych relacji historycznych, związków politycznych pomiędzy państwami Europy Środkowej, jak i dokonań poszczególnych pisarzy i badaczy jej kultury.

Kiss rozważa dzieje podstawowych pojęć budujących współczesną świadomość wspólnoty kulturowo-narodowej w państwach Europy Środkowej, takich jak: "pamięć”, „jedność etniczno-językowa”, „mit 
narodowy”, „symbol narodowy”, „topos śmierci narodu", rozpatrując zawiłe losy małych narodów poszukujących samookreślenia w obrębie wielkich imperiów. Autor analizuje policentryczność tej części kontynentu i polifoniczność narracji tworzących, spajających oraz utrwalających poczucie narodowej wspólnoty w obrębie poszczególnych grup społecznych, interpretując treść hymnów narodowych. Te emblematyczne teksty literackie, które umocniły i odrodziły pojęcie "narodu”, „ojczyzny”, "pamięci historycznej” traktuje Kiss jako szczególny wyraz symbolicznej wyobraźni związanej $\mathrm{z}$ duchową i mityczną historią narodu. O znaczeniu tych utworów decyduje przede wszystkim wartość zdeponowanych $\mathrm{w}$ strukturze tekstu narodowych obrazów, historycznych symboli, czy geograficznej mitologii dotyczącej danego narodu. Idylliczne wizerunki kraju (arkadyjski mit krainy Kunság w hymnie węgierskim), laudacja rajskiej krainy i odrodzenie państwa na wzór odradzającej się przyrody (hymn czeski), czy wizja rzeki Maricy, jako śmiertelnie rannej wdowy (hymn bułgarski) określają zatajone tęsknoty i pragnienia ludzi identyfikujących się z konkretną przestrzenią, krajem, czy językiem, stając się ważnym źródłem wiedzy o kulturowych schematach tworzących mitologię narodu.

Autor Lekcji Europy Środkowej rozważa słuszność idei stworzenia podręcznika o Europie Środkowej, który „mógłby okazać się pomocny w należytym wyeksponowaniu trudno uchwytnych rysów oryginalnych literatury środkowoeuropejskiej, w ukazaniu owej niepowtarzalnej tkaniny, mieniącej się różnymi narodowymi barwami" (s. 123). Wizerunek Mitteleuropy, którym zajmuje się Kiss, obejmuje zarówno nostalgiczno-krytyczne debaty przepełnione dystansem i sceptycyzmem, jak i teksty epatujące zaskakującą fascynacją „egzotyką" małych krajów pomiędzy Łabą a Dunajem, Dniestrem a Cisą. Myślenie o Europie Środkowej w kategoriach jej literackich reprezentacji i "państwotwórczej” natury wiąże się zatem $\mathrm{z}$ równoległym rozpatrywaniem niekwestionowanej wartości dziedzictwa kulturowego tego regionu (np. dzieła Kafki, Rilkego, Musila, Wyspiańskiego, Adyego, Krležy, Haška, Schulza, Krúdyego) oraz przeczucia, że wszelkie praktyki twórcze i dokonania mieszkańców Europy Środkowej są ciągle opatrywane napisem ubi leones. Wszystkie pojęcia, przy pomocy których próbujemy zdefiniować Europę Środkową, można zamknąć w formule "bycia pomiędzy": pomiędzy obszarami kulturowymi, językami, granicami państwowymi. Jest to egzystencja „w środku klepsydry" (określenie Árpáda Tözsera), w „przełyku” Europy (s. 129). Trudno bowiem o uniwersalne wzory, schematy, czy konwencje, które pozwoliłyby ująć jej mozaikową, skomplikowaną naturę.

Kiss analizuje trudne relacje sąsiedzkie pomiędzy Węgrami i Słowakami przywołując dzieje wspólnych losów, debat politycznych i religijnych, ale także sugerując, że przykład ojczystego kraju można i należy potraktować jako metaforę całej Europy Środkowej, w której nie ma wyraźnych granic, w której ze szczególną łatwością rozpadają się ramy państwa narodowego, $\mathrm{w}$ której konieczne jest ponowne zbudowanie świadomości pogranicza, „kresów” („kresowości”) i ich wartości. Węgierski badacz prezentuje te problemy, proponując równoległą lekturę dzieł najważniejszych polityków, pisarzy i historyków idei Mitteleuropy: Milana Hodžy, László Németha, Emanuela Rádla, Luciana Blagi, Istvána Bibó, Kálmána Mikszátha, Gyuli Krúdyego, Czesława Miłosza, Stanisława Vincenza. W debacie o Europie Środkowej wybrał 
Kiss podwójną perspektywę wyznaczoną przez "krąg wewnętrzny”, ukazujący problemy konkretnych mniejszości, wspólnot regionalnych, małych narodów oraz ich lokalnych zamiłowań, upodobań, tradycji oraz "krąg zewnętrzny" - związany z filozofią dziejów, wielkimi przemianami polityki i historii. Narracje obu tych kręgów są ściśle ze sobą splecione i każda z nich - jak dowodzi Autor - jest niezbędna, by zrozumieć istotę Europy Środkowej. Czy stanie się ona kiedyś Europą „rodzinną” zależy wyłącznie od tego, czy uda się rzetelnie odrobić lekcję wspólnej historii, kultury, tradycji. Książka Kissa jest znakomitym podręcznikiem do tego przedmiotu.

(Kinga Piotrowiak-Junkiert)

Lajos Grendel, A modern irodalom története. Magyar líra és epika a 20. században. Pozsony, 2010, Kalligram, ss. 512.

Historia literatury modernistycznej. Wegierska poezja i proza w XX wieku jest przykładem nietypowego przewodnika po węgierskiej literaturze modernizmu. Lajos Grendel (ur. 1948) - wieloletni wykładowca literatury węgierskiej na Uniwersytecie Komeńskiego w Bratysławie, pisarz, redaktor, krytyk literacki, laureat prestiżowej nagrody im. Kossutha - podkreśla, że jego książka nie jest ani podręcznikiem, ani „literackim bedekerem", ale autorską propozycją lektury, która ma przybliżyć istotę najważniejszych zjawisk, prądów i przemian dokonujących się $\mathrm{w}$ obrębie literatury modernistycznej na Węgrzech.

Każda z dziewięciu części Historii literatury modernistycznej prezentuje kolejne etapy przemian literackich - od pierwszych zwiastunów modernizmu w literaturze węgierskiej (E. Ady, M. Babits, Gy. Juhász), przez dokonania dwóch pokoleń twórców zrzeszonych wokół pisma „Nyugat” (,Zachód"), węgierską awangardę poetycką (L. Kassák), poezję i nowelistykę węgierską okresu międzywojennego (A. József, L. Szabó, M. Radnóti, I. Vas, F. Móra, S. Márai, T. Déry, L. Németh), aż po tzw. "literaturę upaństwowioną" (J. Pilinszky, S. Csoóri, I. Örkény, M. Mészöly). Prezentowane problemy literackie uzupełniają noty biograficzne wybranych autorów, fragmenty utworów poetyckich oraz wskazówki bibliograficzne.

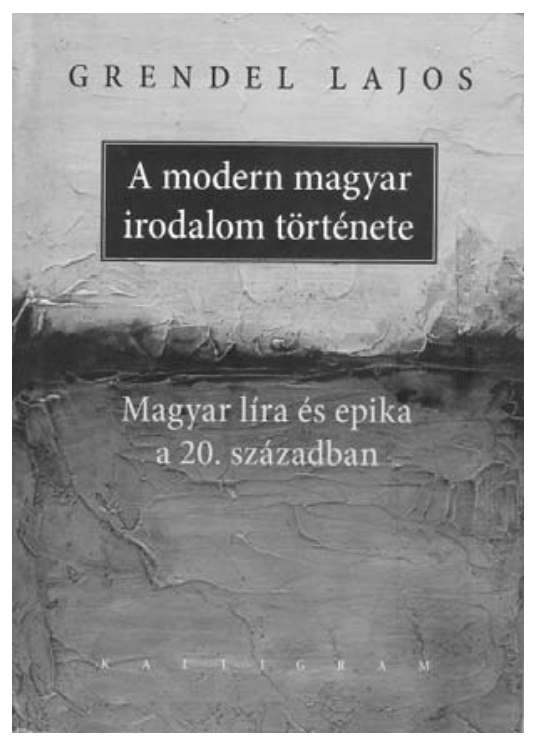

Zawartość treściowa książki i jej kompozycja wyraźnie wskazują obszar prywatnych fascynacji literackich Grendla, który jak sam przyznaje - świadomie narzuca subiektywną wizję węgierskiej literatury modernistycznej i arbitralnie wytycza ramy poszukiwań badawczych. Można potraktować tę taktykę pisarską jako zaletę, ponieważ Autor koncentruje się na autorach i arcydziełach, które są dla niego najważniejsze, najciekawsze, zaskakując niezwykle 